\title{
BOEKBESPREKING
}

L. Leopold: Nederlandse Schrijvers en Schrijfters. I. Wolters, Groningen, 1954 (15de druk); 452 bl.; prys f.6.50 (ongeveer 13/-).

W. L. M. E. van Leeuwen: Beknopt Overzicht van de Nederlandse Letterkunde. Wolters, Groningen, 1954 (11de druk); 169 bl.; prys f.3.40 (ongeveer $7 /-$ ).
W. L. M. E. van Leeuwen: Epiek en Lyriek. Wolters, Groningen, 1954 (10de druk); 338 bl.; prys 6.50 (ongeveer 13/-.

Die werk van Leopold (geredigeer deur W. L. Brandsma) is 'n bloemleslng uit die Noord- en Suid-Nederlandse letterkunde, vanaf die Middeleeue tot teen die elnde van die 19de 
eeu (tot net voor die Tagtigers). Dit is 'n heel uitgebreide bloemlesing (met kort biografleë en portrette van die skrywers/skryfsters) wat die bekendste werke (uittreksels uit die langeres) van die bekendste Nederlandse skrywers bevat. By al die tekste is verklarings van minder bekende en moeilike woorde of konstruksies gegee. Dit is nie 'n werk vir gevorderde studie nie maar heel geskik vir skoolgebruik.

Van Leeuwen se Oorsig van die Nederlandse Letterkunde is, soos dit in die titel lui, inderdaad beknop (aan Vondel word bv, 4 bladsye gewy). Dit is daarom 'n naslaanwerk wat die belangrikste gegewens van die belang rikste Nederlandse skrywers bevat; so objektief moontlik geskryf. Dit is dus nie 'n boek van interpretasies van skrywers se werke of oeuvres nie. Van Leeuwen begin sy beknopte oorsig met die Middeleeue en eindig met die tydperk 1920 tot hede. Die boek bevat 'n aantal pragtige afdrukke (miniature, etse, skilderye).

Die belangrikste van die drie werke hierbo aangekondig is Van Leeuwen se Fpiek en Lyriek. Dit is ' $n$ leesboek bedoel vir Nederlandse middelbare en kweekskole, en dit kan beslis ook 'n groot waarde hè vir Afrikaanse skoliere en minder gevorderde studente Ons het in Afrikaans niks wat vergelykbaar is met Van Leeuwen se werk nie, al is daar in ons taal al min. der of meer breedvoerig oor dieselfde onderwerp (e) geskryf. En wat die skrywer in hierdie boek behandel. word gewoonlik deur ons in ons letterkunde-onderwys, veral op skool, skromelik verwaarloos. Van Leeuwen begin met 'n algemene uiteensetting van wat epiek is en behandel daarna die verskillende epiese vorme (reisbeskrywing, outobiografie, blografle, sage, mite, legende, fabel, sprokie, roman en baie meer); sy behandeling van elke afdeling en onderafdeling is breedvoerig, helder, insiggewend en met illustratiewe tekste daarby. Sy goed gekose voorbeelde uit die literatuur (nie uitsluitlik Nederlandse nie) verhoog die waarde van sy boek baie. Op die selfde wyse behandel hy vervolgens die Liriek (eers ' $n$ algemene uiteensetting daarna die verskillende liriese vorme: lied, ode, elegie en baie meer). Hierby kom ter sprake allerlei formele aspekte soos die klank en rym van die gedig die verskillende gedigvorme soos die kwatryn, die tersine, sonnet, ens.

Van Leeuwen se boek is baie oorsigtelik geskryf; dit getuig van 'n die pe insig en omvangryke belesenheid. Dit bevat kosbare verduidelikings en toeligtende voorbeelde, soms vir die Afrikaner moeilik bekombare sake uit die vroeëre Nederlandse literatuur.

Van Lceuwen se Epiek en Lyriek is in Suid-Afrika nie onbekend nie; 'n mens kan maar vertrou dat dit bekend genoeg is of sal word.

\section{T. T. CLOETE.}

$$
* *
$$

Sophie Meiring: Die Klein Jakkalsies. Pro Rege-Pers, Bpk., Potchefstroom; $4 / 9$ posvry.

'n Mooi boekie wat soos 'n verfrissende buitjie reën op 'n stowwerige pad uitsak. 'n Boekie wat op elke huisvrou se boekrak hoort en nie net daar moet staan nie maar meer as eenkeer gelees kan word.

Sophie Meiring slaag daarin om, in 'n tiental sketse, vir ons te toon dat die "Klein Jakkalsies", wat tog so onskuldig lyk, so kan aangroei en onbe rekenbare skade aan onsself en wat erger is, aan ons huisgenote en huise aanrig. 
Die sketse, wat 'n beslis Christelike strekking het maar tog geensins prekerig is nie, sal deur oud en jong geniet word.

Ons bly die skryfster opreg dank. baar vir die werkie en verwag stellig nog meer van haar.

C. A. VAN ROOY.

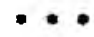

Prof. dr. C. K. Oberholzer: Inleiding in die Prinsipiële Opvoedkunde-nr II van Afrikaanse Wetenskaplike Reeks; J. J. Moreau en Kie., Pretoria en Brugge, 1954; bl. 313.

Hierdie belangrike publikasie van die hoof van die departement Wysbegeerte aan die U.P., 'n oudstudent van die P.U.K. vir C.H.O., wil ek hier net aankondig. Want dit verdien 'n artikel Nie net omdat hierdie werk van besondere betekenis is nie, maar ook omdat ek met die skrywer in diskussie wi tree.

Prof. Oberholzer is ' $n$ positief bely dende Christen. Tog huldig hy 'n neutrale (of soos hy dit uitdruk: 'n waardevrye) wetenskapsbeskouing. Aan die bestaansreg van 'n Christelike wetenskap soos by ons gedoseer, glo hy nie, omdat so 'n wetenskap in 'n waardevoorkeur rus. Vir sy opvatting van wetenskap gee hy deurdagte argumente. Vir ons hier is dit 'n uitdaging waarop ek graag sy weder-antwoord verwelkom. Nie om mekaar te oortuig nie, maar aan die een kant om mekaar beter te verstaan en aan die ander kant om vas te stel of prof Obeholzer se "waardevrye" wetenskap wel werklik so "waardevry" is as wat hy beweer.

Sy teoretiese prinsipiêle (=waardevrye?) opvoedkunde gaan nie net uit van 'n neutrale wetenskapsbeskouing nie, maar ook van 'n eksistensiële (mag ek sê „eksistensialistiese"?) mensbeskouing en 'n (ontologiese?) waardeleer. Vir my bestaan tussen hierdie wetenskapsleer, mensleer en waardeleer kostelike antinomieë. Maar daaroor later.

Op hierdie agtergrond gee hy 'n breed uitgewerkte eksistensiëel-fenomenologiese beskrywing van die "opvoedingsfenomeen", helder, duidelik, kostelik oorspronklik en logies intensief en ekstensief deurdink. Hiervan trek hy sy gevolgtrekkings. Daarna bespreek hy verskillende stromings in die teoretiese opvoedkunde.

Die werk bevat talryke waarheidsmomente, talryke insigte wat tot nadenke prikkel, is boeiend en geesdriftig geskrywe, maar roep veral om sy grondslae (en waarde-bepaaldheid!) asook in sy geheel om indringende verantwoorde kritiek volgens ons Christelik-wetenskaplike visie.

Dit is 'n werk van hoogstaande wetenskaplike karakter en deeglik op die hoogte van die pedagogiese en wysgerige problematiek van ons tyd en geen Fakulteit van Opvoedkunde in ons land asook geen Kollege vir Opleiding van Onderwysers kan die bekostig om hierdie boek links te laat lê nie; inteendeel!

Ons mag dit as 'n verryking van die wetenskaplike literatuur van ons volk verwelkom.

Die uitgawe is keurig versorg, byna drukfoutloos. Die uitgewers verdien hierom alle lof, maar nog mees weens hulle ondernemingsgees wat soos ek weet-eerder deur die ideaal om hoogstaande Afrikaans wetenskap. like literatuur die lig te laat sien as deur die winsmotief gemotiveer word

H. G. STOKER. 
Prof. dr. E. A. Venter: Die Ontwikkeling van die Westerse Denke; SACUM Bpk.; 1955; bl. 144.

As eerste geskrif in Afrikaans oor die geskiedenis van die wysbegeerte en nog meer as 'n geskrif wat hierdie geskiedenis volgens Calvinistiese beginsels afweeg, wil ons graag hierdie studie verwelkom. Dit is 'n verryking van die Christelik-wetenskaplike literatuur in ons land.

Dit is geen leer- of handboek van die geskiedenis van die wysbegeerte nie. Dit behandel nie alle belangrike wysgere nie. Van wysgere wat behandel word gee dit nie altyd alle belangrike insigte of beskouings nie. Dit wil 'n oorsig wees wat die wysgerige denke van 26 eeue in hooflyne vertolk volgens diffl transsendentaal-kritiese metode van prof. dr. H. Dooyeweerd.

Hierdie metode van Dooyeweerd soek die verskillende religieuse grondmotiewe wat die wysgerige denke be paal het. Dooyeweerd onderskei vier dergelike motiewe: a) dié van die Grleke van vorm en materie, b) dié van die Christendom van skepping, sonde en verlossing, c) dié van die Skolastiek (Romanisme, Thomisme) van natuur en genado en d) dié van die moderne humanisme van natuur en vryheid. Hy toon aan dat hierdie motiewe religieus van oorsprong en karakter is en hoo hulle die wysgerige denke rigtinggewend bepaal. Verder toon hy aan dat behalwe die religieuse grondmotief van die Christendom die religieuse grondmotiewe dialekties van aard is, d.w.s met innerlike teëspraak behcp is.

'n Kritiese beoordeling van prof. Venter se werk sou 'n kritiese bespreking van Dooyeweerd se metode van transsendentale kritiek impliseer Daarvoor is hier nie die plek nie. . Ek volstaan met die volgende opmerkings.
Die oopdekking van die (dikwels verborge) religieuse grondmotief van 'n wysgerige stelsel bied 'n ongeëwenaarde diepte van analise en van kritiek. Oortuigend het Dooyeweerd in talle instansies die religieuse grondmotiewe van die betrokke wysgerige stelsels oopgedek. Dit is m.i. egter die vraag of daar nie meer religieuse grondmotiewe van die wysgerige denke is as dié vier en of hierdie vier motiewe nie die betrokke historiese epogge in te vereenvoudigde lig stel nie. Om elke wysgerige stelsel van 'n bepaalde epog in die lig van die betrokke religieuse grondmotief te wil verstaan, herberg die gevaar van 'n kunsmatige vertolking van 'n bepaalde stelsel. Ons mag dan ook nie met ' $n$ betrokke religieuse grondmotief van 'n epog 'n wysgerige stelsel benader nie, maar behoort die religieuse grondmotief van 'n stelsel as grondslag van dárárdie stelsel te ontdek of (omdat hierdie motiewe 'n gemeenskapskarakter dra) opnuut te ontdek

Prof. Venter pas die metode van die transsendentale kritiek van Dooyeweerd globaal op die hele geskiedenis van die wysbegeerte toe. Hierdie geskrif is dan ook groots in opset enmag ek byvoeg-pakkend en duidelik geskryf. Op sy beste is die skrywer waar hy die Thomisme behandel. In sommige instansies is hy nie oortuigend nie en ek sou nie elke siening wat die skrywer van 'n wysgerige stelsel het (bv. dié van Descartes) onderskryl nie. Sommige van sy oordele is m.i te gewaagd. Sommige van sy perspektiewe te vereenvoudig en daardeur eensydig.

Maar hierdie werk is ' $n$ mooi studie wat ons Calvnistiese oortuigings verder begrond en verstewig. Dit laat sien noe ons Calvinistiese beginsels werklik 'n nuwe visie op die wysgerige denke sied. Dit is 'n kostelike uitdaging aan 
elkeen wat die Calvinistiese beginsels atwys. Dit kan as 'n waardevolle handleiding by die bestudering van leer- of handboeke oor die geskiedenis van die wysbegeerte dien. Dit sou meer as die moeite loon as die skrywer sy „Oorsig” tot 'n universitêre leer- of handboek sou wil omwerk. Hierdle geskrif is nie net van belang vir die student en die dosent nie, maar vir elke ontwikkelde leser. Mag daar nog vele geskrifte uit die pen van prof. Venter tot ons kom!

H. G. STOKER.

Onderwysersopleiding, Potchefstroom, 1954.

Daar verskyn min boek sonder outeursnaam (name). Hier is een. In uiterste beskeidenheid vermeld die titelblad dat dit opgestel is deur „Rektor, Personeel en Verteenwoordigende Studenteraad van die Potchefstroomse Onderwyserskollege" (P.O.K.) Dit is geen versamelwerk in die gewone betekenis van die woord nie, want indiwi. duele opvattings van die anonieme outeurs word feitlik nêrens ontdek nie Die boek toon 'n eenheid van gesigspunte asof dit deur een man geskryf is Die skrywers het hulle blykbaar 'n selfdissipline opgelê om as 'n "vitally organised group" hulle inrigting aan die publiek voor te stel.

Ek het die boek met besondere be langstelling gelees en kan nie nalaat om my groot waardering uit te spreek vir sowel inhoud, as die onderskeie vorms van ekspressie nie. $D$ is 'n ver. antwoorde getuienis van die P.O.K. se benadering van die opleidingsvraagstuk, gegrond op kollektiewe insig en ervaring. Die boek gee 'n komplete disseksie van die organisme van hier- die kollege; elke inwendige orgaan kom onder die ontleedmes en die mikroskoop, met die opsetlike doel om sy nuttigheid vir die geheel te demonstreer. Die oogmerk is geensins om eie inisiatief, werkplan of metode as model uit te stal nie, maar uitsluitlik om „die opvoedkundige wêreld tot nadenke te prikkel." Self erken die outeurs in hul versigtige kritiek op eie stelsel in Hoofstuk VIII hoe ver die afstand tot die ideaal nog steeds bly.

Wat my veral in die boek bekoor, is die beklemtoning van die eis vir 'n positief Christelike grondslag in die opleiding. En dit op 'n staatsinstelling! Uit die veelheid van lewens- en wêreldbeskouings word onomwonde die Christelike as die enigste uitgangspunt bely. Ek weet dat tal van humaniste hulle oortuiging ook graag met die woord "Christelike" versier en dus sou hierdie term vir b.v. bewuste Calviniste nie 'n voldoende inhoud hê nie. Maar die toeligting op bl. 49-51 laat geen on sekere geluid hoor nie, al sal daar ongetwyfeld nog wel dogmatici te vin. de wees wat 'n ander formulering sou verkies het. In elk geval, as 'n student die opleidingsinrigting verlaat met 'n lewensbeskouing soos gestel, sal hy aansluiting vind by die meeste van sy volksgenote en klein en groot op die Christelike lewenspad tot steun kan wees.

In verband met bogenoemde uitgangspunt, verbaas dit my enigsins dat in die paragraaf oor die etiese aspek van die persoonlikheidsvorming (bl. 5761) wel oor ,regulerende beginsels" uitgewy word, maar dat daar na dle Tien Gebooie as die enigste volmakkte norm selfs nie verwys is nie terwyl alle Christelike etiek tog alleen in verband met seleksie van kandidate in die Dekaloog sy regulerende beginsels vind. 
Van groot gewig is die nadruk wat die boek lê op die vorming van die a.s onderwyser se persoonlikheid. Die klemtoon van "teachers' training" is daardeur verlê na ,teacher's educa. tion". Dit beteken mos dat die studente nie net voorbereiding ontvang in die onderwystegniek nie, maar veral ook dat hulle stelselmatig gevorm word tot mense wat die onderskeie dissiplines ken. Die P.O.K. spits hom in besonder daarop toe in sy sogenoemde „vyf punt-beleid". 'n Hele aantal verenigings, rade, komitees, leiers en voogde word ingespan om die persoonlikheidsvorming op verskillende gebiede in die hand te werk. Daar is 'n oorvloed van organisasie, spesialisasie, integrasie, evaluasie, ens. en blykbaar loop alles net so perfek as 'n goeie uurwerk.

Ten slotte moet ek 'n paar punte noem wat ek as 'n gemis in die boek gevoel het. In die eerste plaas is daar nèrens gewag gemaak van die voorreg, al dan nie, van die kontak met die Potchefstroomse Universiteit nie. Tweedens, ontbreek paragrawe oor die samewerking, anders as die wetlike, met die Beheerraad (Streekkomitee), oor die waarde van 'n keurkomitee en moontlik die Beroepsvoorligtingsdiens in verband met seleksie van kandidate (sien bl. 172), oor inter-Normaal verhoudings en samesprekings, oor opleidingsnavorsingsprojekte van die personeel. In die derde plek stel die $\mathrm{Bi}$ bliografle teleur deur vir $80 \%$ te verwys na Amerikaanse en Engelse studies, terwyl, aangesien die P.O.K. 'n beslis Christelike opvoedingsinrigting is, moontlik met voordeel ook o.a. kon nagespeur gewees het uit standaard. werke van Christelike Nederlandse opvoedkundiges.

Egter, soos reeds gesê, is dit 'n mooi boek, 'n seldsame produk van treffende eenheid by soveel verskeidenheid, 'n inspirerende pleidooi vir die oorheersende waarde van persoonlikheidsvorming, ' $n$ beskeie voorstelling van moderne opleidingspraktyk, in kort 'n vrymoedige openbaring van grondslag, doel en strewe van die P.O.K., onder die dissiplinerende leiding van die Hoof, prof. P. J. van der Merwe.

A. K. BOT. 